\title{
ENVIRONMENTAL CHANGES OF THE ARAL SEA (CENTRAL ASIA) IN THE HOLOCENE: MAJOR TRENDS
}

\author{
Sergey K Krivonogov ${ }^{1,2} \bullet$ Yaroslav V Kuzmin ${ }^{1}$ George S Burr ${ }^{3}$ Sergei A Gusskov ${ }^{4}$ \\ Leonid B Khazin ${ }^{4}$ Eugeny Y Zhakov ${ }^{4}$ Aijaryk N Nurgizarinov ${ }^{5}$ Rakhat Kh Kurmanbaev ${ }^{5}$ \\ Temirbolat I Kenshinbay 5
}

\begin{abstract}
Changes of the Aral Sea level have been observed in 3 sediment boreholes, 2 outcrops, and associated archaeological sites. The obtained results are supported by 25 radiocarbon dates. Major trends of lake-level changes have been reconstructed in some detail for the last $2000 \mathrm{yr}$, and additional data provide an outline of fluctuations throughout the Holocene. Several distinct changes are shown to precede the modern, human-induced regression of the Aral Sea. These include: 1) the latest maximum in the 16th-20th centuries AD (53 m asl); 2) a Medieval "Kerderi" minimum of the 12th-15th centuries AD (29 m asl); 3) the early Medieval maximum of the 4th-11th centuries AD (52 m asl); and 4) a near BC/AD lowstand, whose level is not well established. Since then, events are only inferred from sparse data. The studied cores contain several sandy layers representing the lowering of the lake level within the Holocene, including the buried shore-bar of $\sim 4500$ cal BP (38 m asl), and shallow-water sediments of $5600 \mathrm{cal} \mathrm{BP} \mathrm{(44} \mathrm{m} \mathrm{asl),} 7200 \mathrm{cal} \mathrm{BP} \mathrm{(28} \mathrm{m} \mathrm{asl),} \mathrm{and} 8000 \mathrm{cal} \mathrm{BP} \mathrm{(26.5} \mathrm{m} \mathrm{asl).}$
\end{abstract}

\section{INTRODUCTION}

The Aral Sea in Central Asia (Figure 1) was a large brackish water reservoir 50 yr ago, with abundant biota. Since the early 1960s, its level began to drop. In 2000, the area of the lake had decreased by a factor of 4, and the water volume declined to 10 times less than in the 1960s. The AD 2008 level is less than $30 \mathrm{~m}$ above the mean Baltic Sea level (hereafter asl). The Aral Sea is now broken into 3 shallow basins (Figure 1, shaded), and its southeastern part is about to disappear. This disastrous situation is usually attributed to the extensive use of water from the 2 major rivers that feed the lake, Amu Dar'ya and Syr Dar'ya, for irrigation (e.g. Middleton 2002). But did such environmental catastrophes occur previously or is this a unique phenomenon from our industrial era? In order to find the answer, a detailed study of past lake levels is required.

The fact that the Aral Sea is a notably changeable body of water became clear after the pioneering study by Berg (1908). He drew the first curve of the level fluctuations from the early 1900s to AD 1780 , based on historical evidence and instrumental data. Later, this curve was extended to the early 2000s (Shermatov et al. 2004). According to these data, the range of lake-level changes throughout the last $200 \mathrm{yr}$ (up to AD 1970 when the fast drop of the level began) was $\sim 3 \mathrm{~m}$. This shows the natural variability of the Aral Sea level during its transgressive phase, over the last 2 centuries, and before the 1960s.

Until the early 2000s, the main ideas about the development of the Aral Sea environment and changes in lake level were based primarily on geomorphologic, geological, biostratigraphic, and archaeological evidence (e.g. Veinbergs and Stelle 1980; Kes 1983; Shnitnikov 1983; Rubanov et al. 1987) that lacked geochronological control. In the 1970s, about 100 short cores (up to $4.5 \mathrm{~m}$ long) were taken from the Aral Sea bottom for lithological, paleontological, and ${ }^{14} \mathrm{C}$ studies. About $30{ }^{14} \mathrm{C}$ dates were obtained, mainly on bulk carbonates and organics (see Appendix). However, these results

\footnotetext{
${ }^{1}$ Institute of Geology \& Mineralogy, Siberian Branch of the Russian Academy of Sciences, Koptyug Ave. 3, Novosibirsk 630090, Russia.

${ }^{2}$ Corresponding author. Email: carpos@uiggm.nsc.ru.

${ }^{3}$ NSF-Arizona AMS Laboratory, University of Arizona, Tucson, Arizona 85721-0081, USA.

${ }^{4}$ Institute of Petroleum Geology \& Geophysics, Siberian Branch of the Russian Academy of Sciences, Koptyug Ave. 3, Novosibirsk 630090, Russia.

${ }^{5}$ Kyzylorda State University, Aiteke Be Str. 29A, Kyzylorda 120014, Kazakhstan.
}

(C) 2010 by the Arizona Board of Regents on behalf of the University of Arizona Proceedings of the 20th International Radiocarbon Conference, edited by A J T Jull RADIOCARBON, Vol 52, $\mathrm{Nr} 2-3,2010$, p 555-568 
were unsuitable for paleoenvironmental purposes (e.g. Rubanov et al. 1987), and only data from sediment cores 15 (Maev et al. 1983) and 86 (Maev and Karpychev 1999) (see Figure 1) were used to understand the history of the Aral Sea (e.g. Ferronskii et al. 2003). Some data were obtained in the 2000s (e.g. Nourgaliev et al. 2003; Sorrel et al. 2006, 2007; see Appendix) and a consensus view of Holocene lake level was established (Tarasov et al. 1996:108-14; Boomer et al. 2000, 2009).

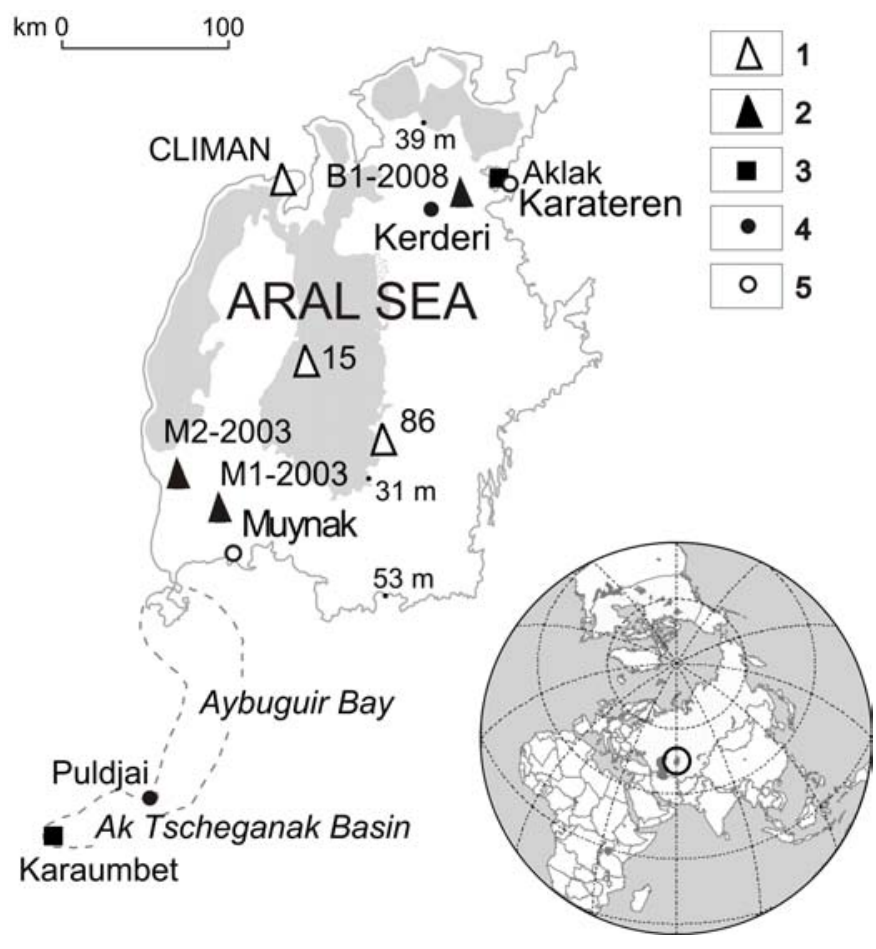

Figure 1 Location of the studied sites: 1-boreholes of previous investigators; 2-boreholes used in this study; 3-outcrops; 4-archaeological sites; 5-towns. Dots with numbers indicate former and recent (AD 2008) lake levels.

Analysis of previous research shows that the chronological framework of the Aral Sea environmental changes in the Holocene is unsatisfactory by modern standards (e.g. van de Plassche 1986). Our research addresses the need to establish a firm chronology for the Aral Sea lake level, which reflects the ecosystem's response to natural and anthropogenic factors, and identifies significant paleoenvironmental events such as transgressions and regressions.

\section{MATERIAL AND METHODS}

Basic data about the Aral Sea changes used in this study come from boreholes drilled on the dry bottom of the lake, outcrops on the former shore, and archaeological sites (Figure 1). Three boreholes were obtained in the northern and southern parts of the basin (Table 1). The sediments are of lacustrine origin, and the entire length of the core contains mollusk shells, foraminifers, and ostracods. The facies structure of deposits is quite complicated, and it reflects the sedimentation conditions determined mainly by lake-level fluctuations. Both transgressive and regressive facies are well recognized in the cores (e.g. Svitoch 2009): the transgressive sediments consist of monotonous silts, and the regressive ones of silty sands and sands. Sandy layers were accumulated in shallow water nearshore conditions and in some cases represent beach-ridges. 
Table 1 Cores of the Aral Sea bottom sediments used in this study.

\begin{tabular}{|c|c|c|c|c|c|}
\hline Core ID & $\begin{array}{l}\text { Latitude (N), } \\
\text { longitude (E) }\end{array}$ & $\begin{array}{l}\text { Altitude } \\
\text { (m asl) }\end{array}$ & $\begin{array}{l}\text { Core length } \\
\text { (m) }\end{array}$ & $\begin{array}{l}\text { Suggested }{ }^{14} \mathrm{C} \\
\text { age of bottom } \\
\text { of core (yr BP) }\end{array}$ & Source \\
\hline B1-2008 & $45^{\circ} 53^{\prime} \mathrm{N}, 60^{\circ} 43^{\prime} \mathrm{E}$ & 39.0 & 11.0 & $20,000^{\mathrm{a}}$ & $\begin{array}{l}\text { Krivonogov, this } \\
\text { study }\end{array}$ \\
\hline M1-2003 & $43^{\circ} 55^{\prime} \mathrm{N}, 58^{\circ} 41^{\prime} \mathrm{E}$ & 50.0 & 8.2 & 6000 & $\begin{array}{l}\text { Krivonogov, CLI- } \\
\text { MAN Project }\end{array}$ \\
\hline M2-2003 & $44^{\circ} 17^{\prime} \mathrm{N}, 58^{\circ} 19^{\prime} \mathrm{E}$ & 36.0 & 20.0 & 9000 & \\
\hline $86^{\mathrm{b}}$ & $44^{\circ} 25^{\prime} \mathrm{N}, 59^{\circ} 59^{\prime} \mathrm{E}$ & 30.0 & 4.08 & 6000 & $\begin{array}{l}\text { Maev et al. 1983; } \\
\text { Maev and Maeva } \\
1991\end{array}$ \\
\hline $15^{\mathrm{b}}$ & $\begin{array}{l}\sim 75 \mathrm{~km} \text { NNW of } \\
\text { Core } 86\end{array}$ & 27.0 & 3.7 & 12,000 & \\
\hline $\begin{array}{l}\mathrm{CH} 1 \text { and } \\
\mathrm{CH} 2\end{array}$ & $45^{\circ} 58^{\prime} \mathrm{N}, 59^{\circ} 14^{\prime} \mathrm{E}$ & 7.2 & $\begin{array}{c}11.04 \text { (CH1), } \\
6.0 \text { (CH2) }\end{array}$ & 1600 & $\begin{array}{l}\text { Austin et al. 2007; } \\
\text { Sorrel et al. } 2007\end{array}$ \\
\hline $\begin{array}{l}\text { Ar7, Ar8, } \\
\text { and Ar9 }\end{array}$ & $\begin{array}{l}45^{\circ} 58^{\prime} \mathrm{N} ; 59^{\circ} 14^{\prime} \mathrm{E} \\
\text { (approximately) }\end{array}$ & $\begin{array}{l}\text { 8.8 (Ar7); } \\
6.3(\operatorname{Ar} 8) ; \\
6.5(\operatorname{Ar} 9)\end{array}$ & $\sim 6.0$ & 1200 & $\begin{array}{l}\text { Nourgaliev et al. } \\
2003\end{array}$ \\
\hline
\end{tabular}

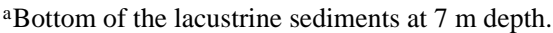

${ }^{b}$ Data from Tarasov et al. (1996).

Using these sedimentological criteria, we determined Aral Sea levels as higher than the hypsometric position of sediments (clays and silts) or proximal to the elevation of nearshore deposits (sands). The low levels of the lake should be reflected as stratigraphic hiatuses, although we cannot visually identify them in the studied cores. The elevation of each core was determined using standard GPS equipment, using a digital model of the Aral Sea bottom topography inferred from a navigational map (scale 1:200,000). We employed a simple model for the filling of the Aral Sea depression with sediments, without taking into account possible tectonic movements. The AD 1960 level of the Aral Sea ( $\sim 53 \mathrm{~m}$ asl) served as a reference elevation.

In Core M1-2003, 4 layers were determined: 2 transgressive and 2 regressive stages (Figure 2). In Core M2-2003, sand layers are found only in the middle part of the 20-m sequence, at depths of 7.2 and 8.5-9.4 m (Figure 2). Core B1-2008 has a complex structure, with 6 sand layers of different thickness (Figure 2). In the regression layers, the mollusk shells are usually plentiful, and this allows us to use them for accelerator mass spectrometry (AMS) ${ }^{14} \mathrm{C}$ dating. Mainly, the shells of Cerastoderma glaucum Poiret (formerly Cardium edule L.) were ${ }^{14} \mathrm{C}$ dated. Some samples were represented by gastropod Caspiohydrobia Starobogatov shells and ostracods collected after paleontological study of the core with special care to prevent their contamination by modern organics. Dating of shells follows a routine AMS protocol for carbonates (e.g. Kuzmin et al. 2007). Samples were analyzed at the NSF-Arizona AMS Laboratory (University of Arizona, Tucson, Arizona, USA; lab code AA). The ${ }^{14} \mathrm{C}$ dating of wood and animal bones from archaeological sites was performed at the Institute of Geology \& Mineralogy (Siberian Branch of the Russian Academy of Sciences, Novosibirsk, Russia; lab code SOAN). Bone samples underwent standard collagen extraction procedures, and wood samples were subjected to acid-base-acid pretreatment. Dates were then obtained by liquid scintillation counting (e.g. Kuzmin and Orlova 2004). Calibration of the raw ${ }^{14} \mathrm{C}$ values was done with the help of the CALIB 6.0 program (www.calib.org) using the IntCal09 calibration data (Reimer et al. 2009), with a reservoir age correction of $\Delta \mathrm{R}=-128 \pm 53 \mathrm{yr}$ for mollusk shells (Kuzmin et al. 2007:465). All calibrated values are $\pm 2 \sigma$ and rounded to the next $10 \mathrm{yr}$ (Tables 2-3). 


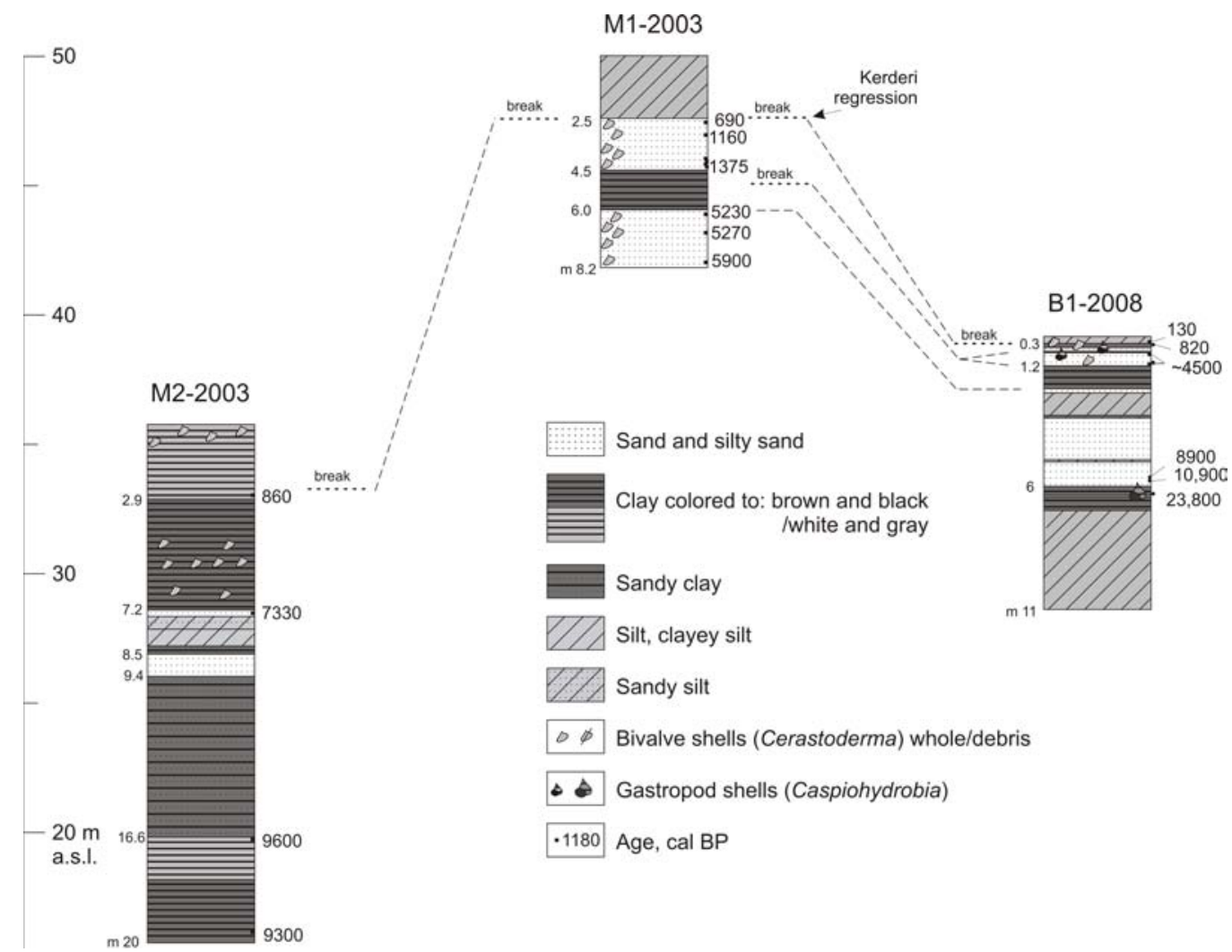

Figure 2 Boreholes used in the study (lithology and age) (see Tables 1-2). Ages are given as average values of the calibrated time intervals.

The evidence for lake highstands was studied in coastal outcrops (Figure 1). The Karaumbet section $\left(43^{\circ} 07^{\prime} \mathrm{N}\right.$; $\left.58^{\circ} 15^{\prime} \mathrm{E}\right)$ is $150 \mathrm{~km}$ from the AD 1960 Aral Sea shoreline, in the southern part of its former bay, recorded by Butakoff (1853) as Aybuguir or Laudan and now referred to as Ak Tscheganak. Here, salt deposits occur at an elevation of about 38-40 m asl; a well-preserved shoreline marks the maximal transgression at $\sim 54 \mathrm{~m}$ asl. This 3-m-thick section of lake deposits is visible in the wall of a small creek. The elevation of the top of the Karaumbet section is $\sim 45 \mathrm{~m}$ asl. Two layers with abundant Cerastoderma glaucum shells, at depths of 0.5 and $2 \mathrm{~m}$ (elevations of $\sim 44.5$ and $\sim 43$ $\mathrm{m}$ asl, respectively) were observed. These sediments are separated by both lacustrine and nearshore deposits (Reinhardt et al. 2008). Another locality with transgressive deposits is on the bank of the Syr Dar'ya River $\sim 15 \mathrm{~km}$ upstream from the AD 1960 mouth $\left(46^{\circ} 01^{\prime} \mathrm{N} ; 61^{\circ} 03^{\prime} \mathrm{E}\right)$. Here, the Aklak Dyke is being built (Figure 1). Due to the artificial lowering of the Sur Dar'ya level to $\sim 50.5 \mathrm{~m}$ asl, deltaic and underlying lacustrine sediments were exposed. The top of the lacustrine stratum shows that the level was $\sim 52 \mathrm{~m}$ asl.

The pre-modern regression is detected by archaeological sites on today's dry bottom of the Aral Sea. Archaeologists have discovered 2 sites, Kerderi I and Kerderi II (Smagulov 2001, 2002), located east of the former Barsa-Kel'mes Island (Figure 1). These sites are located $\sim 60 \mathrm{~km}$ from the AD 1960 shoreline at an elevation of $\sim 34 \mathrm{~m}$ asl. During the last transgression, they were covered by $\sim 20 \mathrm{~m}$ of water. The Kerderi II site includes a settlement and mausoleum (or mazar in local terminology), spaced $4.5 \mathrm{~km}$ apart. The archaeological age determination of these sites varies: the end of the 13th-14th centuries AD (Smagulov 2002); 15th-16th centuries AD (Boroffka et al. 2005); 14th- 
Table $2{ }^{14} \mathrm{C}$ dates for the boreholes and outcrops of the Aral Sea region used in this study.

\begin{tabular}{|c|c|c|c|c|c|c|c|}
\hline $\begin{array}{l}\text { Depth } \\
\text { (cm) }\end{array}$ & Material & $\begin{array}{l}\text { Lab nr } \\
\text { (AA-) }\end{array}$ & $\begin{array}{l}\text { Uncalib- } \\
\text { rated date } \\
\text { (yr BP) }\end{array}$ & $\begin{array}{l}\delta^{13} \mathrm{C} \\
(\%)\end{array}$ & $\begin{array}{l}\text { Calibrated } \\
\text { age } \\
\text { (cal yr BP) }\end{array}$ & $\begin{array}{l}\text { Water } \\
\text { level } \\
\text { (m asl) }\end{array}$ & $\begin{array}{l}\text { Trend of the } \\
\text { level change }\end{array}$ \\
\hline \multicolumn{8}{|c|}{ Core M1-2003 (50 m asl) } \\
\hline $260-270$ & Shell of Dreissena & 59339 & $1010 \pm 30$ & +1.0 & $560-820$ & 47.4 & Regressive \\
\hline $310-320$ & Shell of Cerastoderma & 59340 & $1485 \pm 30$ & +1.1 & 1030-1290 & $>46.9$ & Transgressive \\
\hline $400-410$ & Shell of Cerastoderma & 61833 & $1330 \pm 40$ & +1.1 & 880-1180 & $>46$ & Transgressive \\
\hline $420-430$ & Shell of Cerastoderma & 61834 & $1580 \pm 40$ & +0.9 & $1110-1400$ & $>45.8$ & Transgressive \\
\hline $430-440$ & Shell of Cerastoderma & 61835 & $1675 \pm 40$ & +0.2 & $1240-1510$ & $>45.7$ & Transgressive \\
\hline $620-630$ & Shell of Cerastoderma & 59342 & $4790 \pm 40$ & -0.9 & $5030-5430$ & $>43.8$ & Transgressive \\
\hline $690-700$ & Shell of Cerastoderma & 59343 & $4840 \pm 40$ & +0.3 & $5070-5470$ & $>43.1$ & Transgressive \\
\hline $800-810$ & Shell of Cerastoderma & 59344 & $5385 \pm 40$ & +0.6 & $5720-6080$ & $>42$ & Transgressive? \\
\hline \multicolumn{8}{|c|}{ Core M2-2003 (36 m asl) } \\
\hline 280-292 & Shells of ostracods, gastropods & 83691 & $1190 \pm 60$ & +0.9 & 690-1030 & $>33.2$ & Regressive \\
\hline $720-752$ & Shells of ostracods & 83690 & $6690 \pm 80$ & -2.7 & $7150-7510$ & 28.8 & Unclear \\
\hline $1660-1672$ & Shells of ostracods & 83689 & $8740 \pm 95$ & -3.3 & 9300-9870 & >>19.4 & Unclear \\
\hline 1880-1892 & Shells of ostracods, gastropods & 83688 & $8545 \pm 95$ & -3.2 & 9050-9530 & $>>17.2$ & Unclear \\
\hline \multicolumn{8}{|c|}{ Core B1-2008 (39 m asl) } \\
\hline 25-27 & Shell of Cerastoderma & 83393 & $385 \pm 35$ & +2.7 & $0-260$ & $>38.75$ & Transgressive \\
\hline $31-32$ & Shells of Caspiahydrobia & 83394 & $1155 \pm 35$ & +1.0 & $690-950$ & 38.7 & Regressive \\
\hline 69 & Shell of Cerastoderma & 83396 & $4240 \pm 45$ & +1.5 & $4340-4770$ & 38 & Unclear (dis- \\
\hline $100-110$ & Shells of Cerastoderma & 83397 & $4225 \pm 35$ & +1.5 & $4300-4710$ & & tinct beach- \\
\hline 118 & Shells of Cerastoderma & 83398 & $4200 \pm 40$ & +0.5 & $4260-4680$ & & ridge) \\
\hline $560-570$ & Terrestrial plant remains & 86200 & $8030 \pm 130$ & -25.4 & 8560-9290 & 34 & \\
\hline $570-580$ & Terrestrial plant remains & 86199 & $9590 \pm 120$ & -25.8 & $10,590-11,220$ & & \\
\hline 634 & Shell of a gastropod (broken) & 83399 & $19,900 \pm 140$ & -1.6 & $23,370-24,240$ & $>>33.6$ & Deep water \\
\hline \multicolumn{8}{|c|}{ Karaumbet outcrop (45 m asl) } \\
\hline $45-50$ & Shells of Cerastoderma ${ }^{\mathrm{a}}$ & Poz-? & $300 \pm 30$ & - & 0-150 & 44.5 & Regressive \\
\hline $201-210$ & Shells of Cerastoderma ${ }^{\mathrm{a}}$ & Poz-? & $1805 \pm 30$ & - & $1330-1640$ & 43 & Transgressive \\
\hline 210 & Shells of Cerastoderma & 59338 & $1715 \pm 30$ & -0.3 & $1270-1520$ & 43 & Transgressive \\
\hline \multicolumn{8}{|c|}{ Aklak outcrop (54.5 m asl) } \\
\hline 250 & Shell of Cerastoderma & 83390 & $1510 \pm 35$ & +1.1 & $1050-1310$ & 52 & $\begin{array}{l}\text { About the } \\
\text { highest level }\end{array}$ \\
\hline
\end{tabular}

a Dates produced at the Poznań Radiocarbon Laboratory, Poland (Reinhardt et al. 2008); $\delta^{13} \mathrm{C}$ values not given.

Table $3{ }^{14} \mathrm{C}$ dates from the Kerderi II archaeological sites.

\begin{tabular}{llllll}
\hline & & & $\begin{array}{l}\text { Calibrated } \\
\text { Site }\end{array}$ & $\begin{array}{l}\text { Calibrated } \\
\text { (yr BP) }\end{array}$ & $\begin{array}{l}\text { Lab nr } \\
\text { (SOAN-) }\end{array}$ \\
(cal AD) & $\begin{array}{l}\text { age } \\
\text { (cal BP) }\end{array}$ \\
\hline Mausoleum Kerderi II & Thin wood stick & $600 \pm 65$ & 7688 & $1280-1430$ & $670-520$ \\
Mausoleum Kerderi II & Thick wooden plank & $820 \pm 55$ & 7687 & $1150-1280$ & $800-670$ \\
Settlement Kerderi II & Domestic animal bones & $910 \pm 80$ & 7686 & $990-1260$ & $960-690$ \\
\hline
\end{tabular}

early 15th centuries AD (Boroffka et al. 2006); and 13th-14th centuries AD (Boomer et al. 2009). We ${ }^{14} \mathrm{C}$ dated bones of domestic animals (cow, horse, and sheep/goat) from the Kerderi II settlement and pieces of wood from the Kerderi II mausoleum.

\section{RESULTS}

\section{Changes of the Aral Sea Level According to the Data from Boreholes}

The results of AMS ${ }^{14} \mathrm{C}$ dating of samples from 3 cores are given in Table 2. The correlation of sediments based on these data is shown on Figure 2. For Core M1-2003, 2 events of relatively stable 
lake level are detected at $\sim 690-1380 \mathrm{cal}$ BP (47 m asl; depth in core $2.5-4.5 \mathrm{~m}$ ) and $\sim 5200-5900 \mathrm{cal}$ BP (44 m asl; depth in core 6.0-8.1 m); each of them persisted for $\sim 700$ yr. The clays between these 2 layers reflect relatively high lake levels that lasted for approximately $4000 \mathrm{yr}$. The uppermost silt layer is younger than $\sim 700 \mathrm{cal} \mathrm{BP}$ and corresponds to the latest transgression.

In Core B1-2008, the upper layer (0.0-0.3 m depth) accumulated since 130 cal BP. In the interval of 0.3-0.7 m dated to about 800-4500 cal BP, 2 highstands are recognized; they are separated by shallow water events with lake levels of $\sim 38.5 \mathrm{~m}$ asl, unfortunately not constrained with ${ }^{14} \mathrm{C}$ dates. Below the depth of $0.7 \mathrm{~m}$, there is layer $0.5 \mathrm{~m}$ thick with shells of Cerastoderma glaucum, and the ${ }^{14} \mathrm{C}$ values are very uniform throughout it. This can be interpreted as an ancient beach-ridge that was deposited instantaneously in a geological sense. In this case, it shows that the lake level $\sim 4500 \mathrm{cal}$ $\mathrm{BP}$ was at $\sim 38 \mathrm{~m}$ asl. This ridge provides evidence that the deep-water sediments in Core M1-2003 dated to about 1380-5200 cal BP do not belong to a single transgressive phase with a level above 50 $\mathrm{m}$ asl but are separated by at least 1 regression at $\sim 4500 \mathrm{cal} \mathrm{BP}$. However, it is impossible to detect this event in the monotonous sequence of the core, and the hiatus is thus obscured.

An age of about 8900-10,900 cal BP was determined from plant remains in the interval 5.6-5.8 $\mathrm{m}$ in the core B1-2008. The value of $\sim 19,900 \mathrm{BP}$ is generated on a thin-walled shell of a large $(1.5 \mathrm{~cm}$ diameter) gastropod unexpectedly cut by knife in the process of the core splitting, which did not allow to identify its species. The gastropod was placed vertically, probably in living position, in the brown clays, which possibly correspond to the transgressive phase, and were accumulated during the Last Glacial Maximum. Below are dense clays and silts of brownish and bluish colors with scattered gypsum crystals, and this is suggested to be a basal layer of non-lacustrine origin.

Core M2-2003 is taken at the lowest modern elevation among the studied boreholes (Figure 1; Table 1). Clay sediments prevail in this core and show that $20 \mathrm{~m}$ of deposits were accumulated in deepwater conditions. However, 2 sandy layers at depths of 7.2-7.33 and 8.5-9.4 m reflect deep regressions down to levels of $\sim 28$ and $\sim 26 \mathrm{~m}$ asl, respectively. The upper sandy layer is ${ }^{14} \mathrm{C}$ dated to $\sim 7300$ cal BP. The base of this core is ${ }^{14} \mathrm{C}$ dated to $\sim 9500 \mathrm{cal}$ BP.

\section{The High Aral Sea Levels as Seen from Data on the Outcrops}

In the Karaumbet section, the lower layer with mollusk shells dates to about 1300-1600 cal BP (Table 2). This coincides with the highstand of the lake level recorded in Core M1-2003 dated to $\sim 1400$ cal BP. The upper layer with shells has a date of $0-150 \mathrm{cal}$ BP, and this is evidence of the latest transgression. However, in the southernmost part of the Aral Sea basin the situation was different from the rest of the lake. The Puldjai settlement (elevation 53-51 m asl) east of Karaumbet is dated to the 13th-14th centuries AD (Boroffka et al. 2006; Reinhardt et al. 2008). It was flooded by the Aral Sea during the last transgression, and the Aybuguir Bay appeared. Later on, it was separated from the main body of the Aral Sea and turned into a shallow freshwater basin with many reeds; the source of water was the Amu Dar'ya River. This description is known from early sources (Berg 1908). It seems that later the Ak Tscheganak Basin parted from the Aybuguir Bay and became an isolated saltwater body. According to the geological mapping done in AD 1917 (Arkhangelski and Churakov 1930), the level of Ak Tscheganak Basin was $\sim 48 \mathrm{~m}$ asl. The remote sensing data of AD 1962 show that it was completely dry (Reinhardt et al. 2008). Therefore, the upper layer with shells in the Karaumbet section corresponds to a time of shrinking of the Ak Tscheganak Basin in the first part of the 20th century.

In the Aklak section (northern Aral Sea), evidence of the transgression above the level of $52 \mathrm{~m}$ asl is found, and its age is about $1100-1300 \mathrm{cal} \mathrm{BP}$ (Table 2), roughly corresponding to the final part of the first highstand in the Karaumbet section. In Core B1-2008, this event is expressed as deep-water 
sediments below a depth of $0.3 \mathrm{~m}$. The top of these deposits has an age of 690-950 cal BP (Figure 2). This event is also detected in Core M2-2003. Some discrepancy exists in Core M1-2003, where the transgression of about 1100-1300 cal BP falls within a layer of shallow-water sands dated to 690-1375 cal BP (Figure 2), and the level for this period is estimated as close to $47 \mathrm{~m}$ asl. Perhaps such a level was more common for this time interval, but this does not exclude the possibility of a higher level, at $52 \mathrm{~m}$ asl.

Summing up the data from outcrops, we can determine a transgressive event at about 1100-1600 cal $\mathrm{BP}$, and it was as high as the latest one. Although we do not see evidence of the latest ("historic") transgression in the studied outcrops, except for the uppermost layer in the Karaumbet section, historical data summarized by Bartold (1902) and Berg (1908) show that it lasted from the end of the 16th century AD to the middle of the 20th century AD, with a peak in the 16th-17th centuries AD.

\section{The Kerderi Regression and Its Age}

${ }^{14} \mathrm{C}$ dating of the Kerderi II settlement and mausoleum (Table 3) gave ages that are older than archaeological estimates (see above). Pieces of wood overlying the sarcophagus in the burial chamber of the mausoleum were ${ }^{14} \mathrm{C}$ dated. A thin wooden stick dates to the 13 th-15th centuries $\mathrm{AD}$, while a thicker plank is older, within the 12th-13th centuries AD. The difference could be either due to inherited age of the thicker wood fragment or the repeated use of older wood for construction in the treeless region. The age of animal bones from the Kerderi II settlement is even older, in the 10th13th centuries AD (Table 3). However, all ages nearly overlap. The possibility remains that the settlement is about a century older than the mausoleum. Therefore, this very deep regression (deeper than $34 \mathrm{~m}$ asl) is dated to the early Middle Ages, 10th-15th centuries AD. The beginning of the Kerderi regression may be estimated using data from the B1-2008 and M1-2003 cores where the end of the preceding transgressive phase is dated to $690-950$ and 560-820 cal BP, respectively.

The scale of the Kerderi regression is equal to the modern stage of the lake degradation (Boomer et al. 2009). The latest data show that people could settle the dry bottom of the Aral Sea because the Syr Dar'ya River was flowing nearby. It developed a new channel, in excess of $100 \mathrm{~km}$, and an extensive delta that has extended to the western side of the Aral Sea bottom (Krivonogov 2009). According to the position of this ancient delta, the level could be as low as $29 \mathrm{~m}$ asl. The existence of a large delta is also consistent with the relative longevity of the Aral Sea lowstand in the Middle Ages. Therefore, we can assume that the Kerderi regression persisted for 200-300 yr, most probably in the 12th-15th centuries AD.

\section{DISCUSSION}

\section{Resume of Previous Studies of the Aral Sea History}

Modern progress in research aimed at understanding the Holocene history of the Aral Sea began in the late 1960s to early 1970s and resulted in a series of summary papers (e.g. Tarasov et al. 1996; Boomer et al. 2000, 2009). A number of ${ }^{14} \mathrm{C}$ dates were generated from coastal outcrops and boreholes (see Appendix). These results allowed general conclusions to be drawn indicating that the modern Aral Sea existed since at least 7000 BP (e.g. Maev et al. 1983; Maev and Karpychev 1999; Ferronskii et al. 2003) and experienced significant variations in water level. However, these findings did not provide much information about environmental change during the Holocene. The number of mollusk ${ }^{14} \mathrm{C}$ dates substantiating the age model for cores 15 and 86 (Maev et al. 1983; Maev and Karpychev 1999) is small, and hence the reliability of the reconstructions based on it is therefore low, providing only qualitative information (see Tarasov et al. 1996). 
The most important result of previous investigations for our purposes is the establishment of lowstands of the Aral Sea level. For example, Maev et al. (1983) dated an in situ saxaul tree stump to $\sim 970$ BP (Appendix), which shows that the lake level was lower than in AD 1980. A similar specimen was obtained at the Butakov Bay and dated to $\sim 280 \mathrm{BP}$, indicating a level below $\sim 40 \mathrm{~m}$ asl (Appendix). Some highstands of the Aral Sea level were also suggested (e.g. Maev et al. 1983; Tarasov et al. 1996:108-14; Boomer et al. 2000, 2009).

${ }^{14} \mathrm{C}$ dating of bulk carbonates and dispersed organic matter from cores gives unreliable results (Kuptsov 1985; Kuptsov et al. 1982; Maev and Karpychev 1999; see Appendix). This is especially clear for relatively big samples needed for liquid scintillation counting, which yield ${ }^{14} \mathrm{C}$ dates with large uncertainties. These values were later rejected (Ferronskii et al. 2003). It was concluded that the most reliable material for ${ }^{14} \mathrm{C}$ dating in sediment cores are mollusk shells, mainly Cerastoderma glaucum (e.g. Ferronskii et al. 2003).

One of the latest research campaigns took place in the early 2000s under the CLIMAN Project funded by the INTAS Foundation (European Union), which focused on Holocene climatic variability and the evolution of human settlements in the Aral Sea basin. New data reflecting environmental changes in the Aral Sea region over the last 2000 yr were obtained (Nourgaliev et al. 2003; Boroffka et al. 2005, 2006; Sorrel et al. 2006, 2007; Oberhähsli et al. 2007; Reinhardt et al. 2008). However, ${ }^{14} \mathrm{C}$ results from these studies were inconsistent (Sorrel et al. 2006:308).

The Aral Sea level curves obtained by different authors are shown in Figure 3. The general correspondence of results from Tarasov et al. (1996) and Boomer et al. (2000) may be explained by their use of the same original sources. They are different, however, from the curves of Boomer et al.

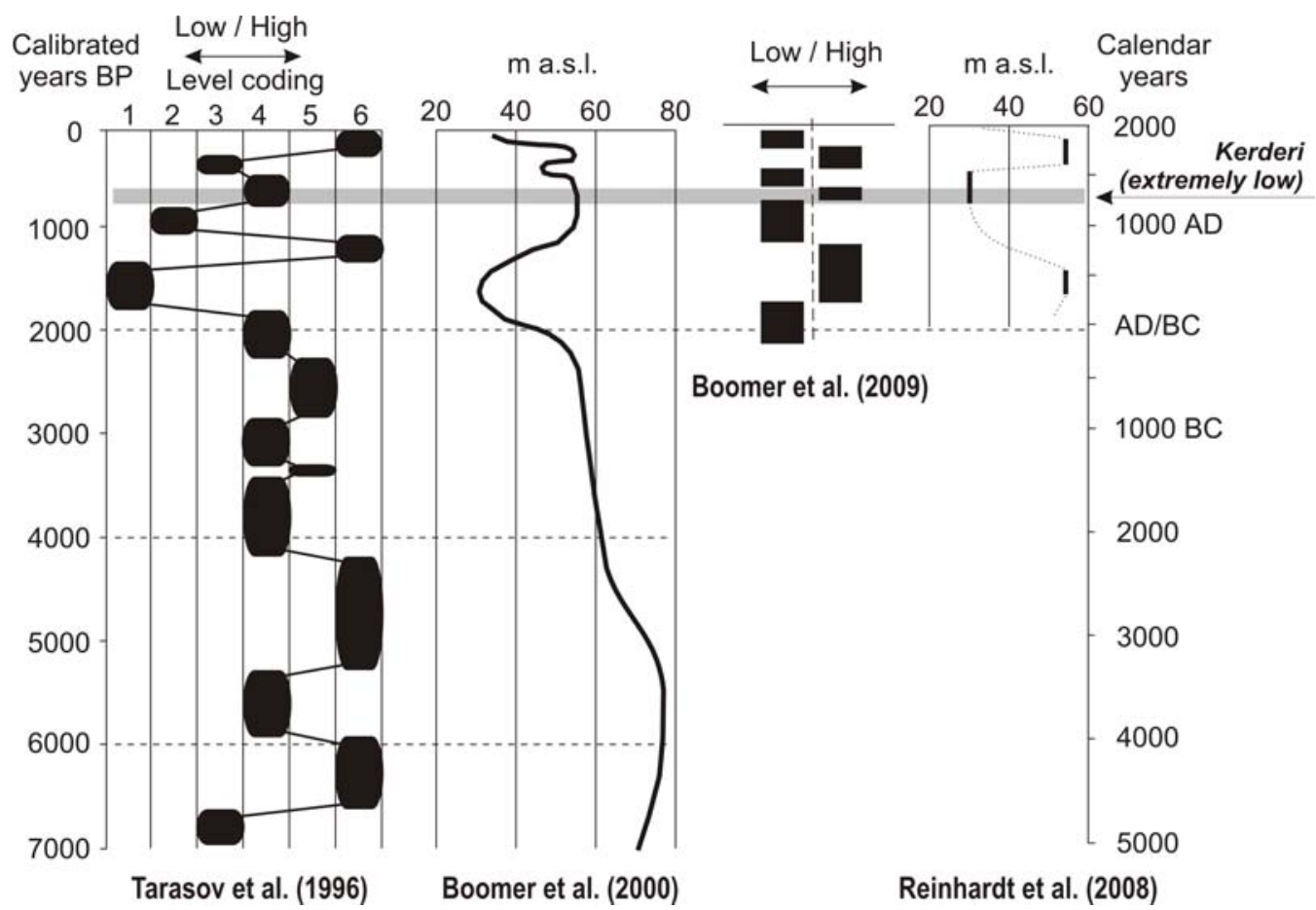

Figure 3 Fluctuations of Aral Sea level in the Holocene (according to different authors) 
(2009) and Reinhardt et al. (2008) based on more recent materials. Nevertheless, the newer data remain inconsistent, and the differences are likely due to the methodologies employed. Boomer et al. (2009) applied mainly paleontological techniques, while Reinhardt et al. (2008) used geomorphological and sedimentological approaches.

\section{Current Problems in the Study of the Holocene History of Aral Sea}

Our tentative knowledge about the fluctuations of the Aral Sea level is summarized in Figure 4. There are a number of problems that hamper precise conclusions. The degree of reliability is not high enough; only the curve for the last $2000 \mathrm{yr}$ is based on good quality data with a high sampling density. It is very similar to the results obtained by Reinhardt et al. (2008) (Figure 3). Going further into the past (from about BC/AD onwards), we have records of some events that are securely established, but they do not yet constitute a unified framework. There is some resemblance with the curve by Tarasov et al. (1996) (Figure 3), but the chronologies of all of the major events are shifted significantly.

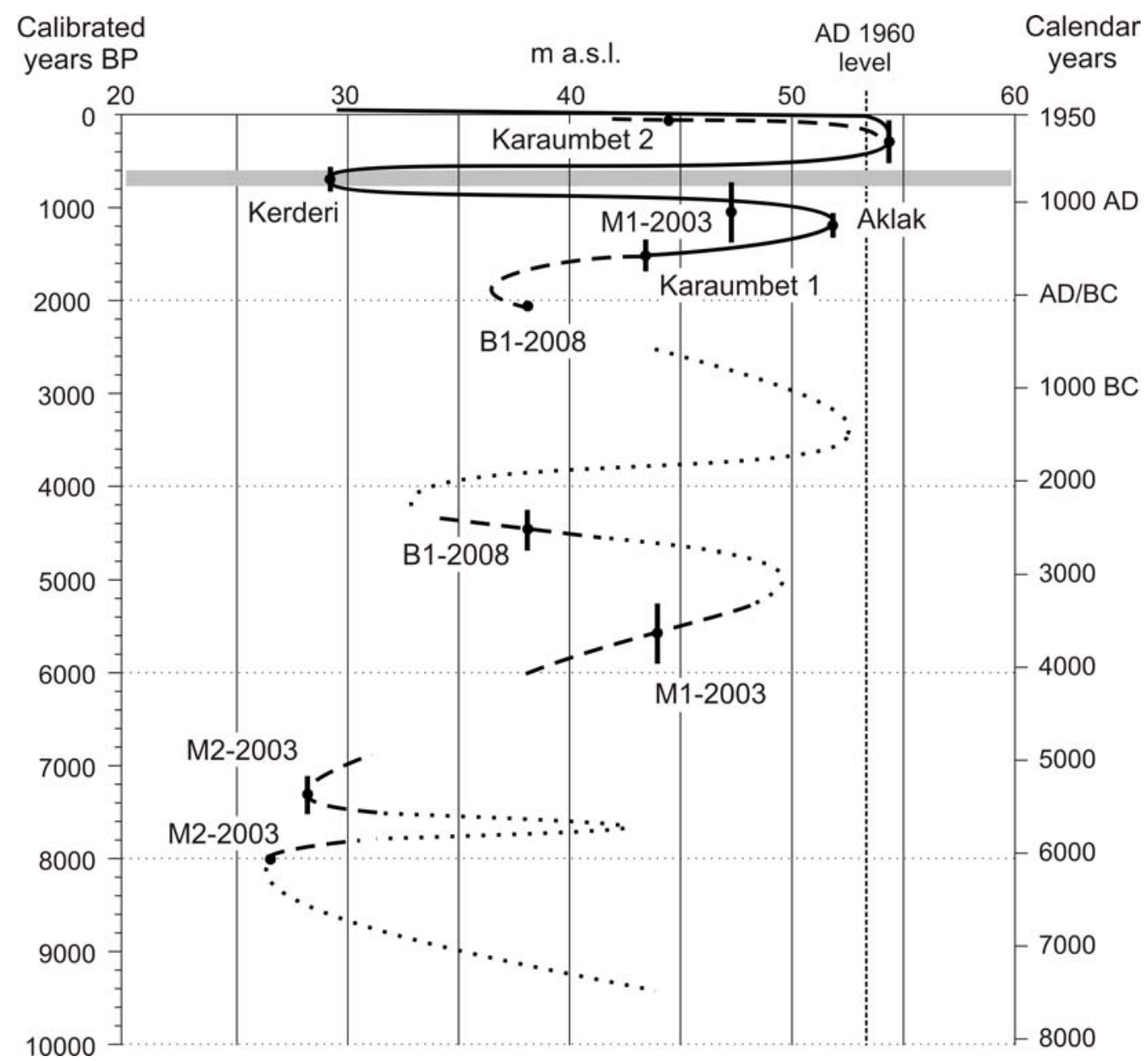

Figure 4 Tentative curve of the Aral Sea level in the Holocene (according to authors' data). Solid line: well substantiated; dashed line: separate events; dotted line: suggested trends. 
The core results demonstrate the utility of the approach for identifying and dating transgressive events. It is very hard to detect regressive phases as they produce hiatuses in the sediment cores. Still, it is possible to infer their existence and place boundaries on their timing. Although the study of deep regressions remains a serious problem, the Kerderi regression (e.g. Krivonogov 2009) is an exception.

The complexity of sedimentation processes in such a changeable reservoir as the Aral Sea is reflected in the numerous facies changes that are impossible to correlate by the study of a few individual cores. Also, layer counting for correlation is not possible due to incomplete sequences, especially where regression events and shifting layer boundaries obscure evidence for a particular facies. This is quite significant for the centennial timescale that we are trying to establish. Increasing the number of reliable ${ }^{14} \mathrm{C}$ dates is perhaps the best tool to reconstruct spatial changes of the Aral Sea level through time.

\section{CONCLUSION}

The understanding of Holocene fluctuations of the Aral Sea is far from complete. We can reliably reconstruct events for the last 2 millennia, including 2 transgressive and 2 regressive phases. Transgressions occurred in the 6th-12th and the 16th-20th centuries $\mathrm{AD}$; the regressions can be dated to the 13th-14th centuries AD (Kerderi) and since the mid-20th century AD. Further into the past, we can only detect broad changes, including a lake level below $40 \mathrm{~m}$ asl at 2000 and $4500 \mathrm{cal} \mathrm{BP}$; and below $30 \mathrm{~m}$ asl at $\sim 7500$ and 8000 cal BP. For the time interval of $\sim 4500-20,000$ cal BP, there was no less than 4 regressive episodes down to 20-36 m asl, but the timings of these events are not yet firmly established.

The discrepancy between our data and results of previous research may well be related to the insecure methods of dating in the past and a lack of calibrated ${ }^{14} \mathrm{C}$ dates using an appropriate $\delta^{13} \mathrm{C}$ and reservoir age correction factors. In order to obtain reliable data, drilling of the dry bottom of the Aral Sea and its extensive ${ }^{14} \mathrm{C}$ dating are necessary. This will allow us to compile geological profiles and to recognize facies structures of the lake deposits.

\section{ACKNOWLEDGMENTS}

We are grateful to the staff of the Arizona AMS Laboratory for assistance with AMS ${ }^{14} \mathrm{C}$ dating of the shell samples. We are also thankful to Dr S K Vasiliev (Institute of Archaeology \& Ethnography, Siberian Branch of the Russian Academy of Sciences, Novosibirsk) for identification of the animal bones from the Kerderi II site; Dr L A Orlova (Institute of Geology \& Mineralogy, Siberian Branch of the Russian Academy of Sciences, Novosibirsk) for ${ }^{14} \mathrm{C}$ dating of the Kerderi II specimens; and the staff of the Barsa-Kel'mes Natural Reserve for logistic support. Prof S Stine (California State University, Hayward, California, USA) provided information for one of the ${ }^{14} \mathrm{C}$ dates. This study is supported by the CRDF-RFBR Project "Environmental history of the Aral Sea in the last 10,000 years: natural and anthropogenic components” (RUG1-2921-NO-07 and 08-05-91105), Programs of the Russian Academy of Sciences (nos. 15, 17), and by the US NSF (0010835000 and EAR06-22305).

\section{REFERENCES}

Arkhangelski A, Churakov A. 1930. Geological Map of the Lower Course of the Amudaria 1917. LeningradMoscow: Geological \& Prospecting Service. In Russian with English translation.

Austin P, Mackay A, Palagushkina O, Leng M. 2007. A high-resolution diatom-inferred palaeoconductivity and sea-level record of the Aral Sea for the last ca. 1600 years. Quaternary Research 67(3):383-93.

Bartold V. 1902. Svedeniya ob Aralskom More i Nyzovyakh Amu-Daryi s Drevneishikh Vremen do XVII Veka [Records on the Aral Sea and the Lower Stream of the Amu Dar'ya since the Earliest Times to the XVIIth 
Century]. Tashkent: Turkestanski Otdel Russkogo Geograficheskogo Obshchestva. 120 p. In Russian.

Berg LS. 1908. Aralskoe More. Opyt FizikoGeograficheskoi Monografii [The Aral Sea. An Experience of Physical-Geographical Monograph]. St. Petersburg: Stasyulevich Publishing. 580 p. In Russian.

Boomer I, Aladin N, Plotnikov I, Whatley R. 2000. The palaeolimnology of the Aral Sea: a review. Quaternary Science Reviews 19(13):1259-78.

Boomer I, Wünnemann B, Mackay AW, Austin P, Sorrel P, Reinhardt C, Keyser D, Guichard F, Fontugne M. 2009. Advances in understanding the late Holocene history of the Aral Sea region. Quaternary International 194(1-2):79-90.

Boroffka NGO, Oberhähsli H, Achatov GA, Aladin NV, Baipakov KM, Erzhanova A, Hörnig A, Krivonogov S, Lobas DA, Savel'eva TV, Wünnemann B. 2005. Human settlements on the northern shores of Lake Aral and water level changes. Mitigation and Adaptation Strategies for Global Changes 10:71-85.

Boroffka NGO, Oberhähsli H, Sorrel P, Demory F, Reinhardt C, Wünnemann B, Alimov K, Baratov S, Rakhimov K, Saparov N, Shirinov T, Krivonogov SK. 2006. Archaeology and climate: settlement and lake level changes at the Aral Sea. Geoarchaeology 21:721-34.

Butakoff A. 1853. Survey of the Sea of Aral in 1848 and 1849. Journal of the Royal Geographic Society 23:93101.

Ferronskii VI, Polyakov VA, Brezgunov VS, Vlasova LS, Karpychev YA, Bobkov AF, Romaniovskii VV, Johnson T, Ricketts D, Rasmussen K. 2003. Variations in the hydrological regime of Kara-Bogaz-Gol Gulf, Lake Issyk-Kul, and the Aral Sea assessed based on data of bottom sediment studies. Water Resources 30: 252-9.

Filippov A, Riedel F. 2009. The late Holocene mollusc fauna of the Aral Sea and its biogeographical and ecological interpretation. Limnologica 39:67-85.

Gorodetskaya ME. 1978. On the Aral Sea terraces. Geomorfologiya 1:46-55. In Russian with English abstract.

Kes AS. 1983. Paleogeografiya Aralskogo morya v pozdnem pleistotsene [Paleogeography of the Aral Sea in the Late Pleistocene]. In: Maev EG, editor. Palaeogeografiya Kaspiiskogo i Aralskogo Morei v Kainozoe. Part 2. Moscow: Moscow State University Press. p 97-106. In Russian.

Krivonogov SK. 2009. Extent of the Aral Sea drop in the Middle Age. Doklady Earth Sciences 428(1):114650

Kuptsov VM. 1985. Radiouglerodnye datirovki Instituta okeanologii im. P.P. Shirshova AN SSSR. Soobshchenie VI [Radiocarbon dates of the P.P. Shirshov's Institute of Oceanology, USSR Academy of Sciences. Report VI]. Bulleten Komissii po Izucheniyu Chetvertichnogo Perioda 54:152-6. In Russian.

Kuptsov VM, Rubanov IV, Zeldina BB. 1982. Radiou- glerodnoe datirovanie donnykh osadkov Aralskogo morya [The radiocarbon dating of the Aral Sea bottom sediments]. Izvestiya Akademii Nauk SSSR. Seriya Geograficheskaya 1:103-8. In Russian.

Kuzmin YV, Orlova LA. 2004. Radiocarbon chronology and environment of woolly mammoth (Mammuthus primigenius Blum.) in northern Asia: results and perspectives. Earth-Science Reviews 68(1-2):133-69.

Kuzmin YV, Nevesskaya LA, Krivonogov SK, Burr GS. 2007. Apparent ${ }^{14} \mathrm{C}$ ages of the 'pre-bomb' shells and correction values $(R, \Delta \mathrm{R})$ for Caspian and Aral seas (Central Asia). Nuclear Instruments and Methods in Physics Research B 259(1):463-6.

Maev EG, Karpychev YA. 1999. Radiocarbon dating of bottom sediments in the Aral Sea: age of deposits and sea level fluctuations. Water Resources 26:187-94.

Maev EG, Maeva SA. 1991. Donnye ortlozheniya Arala [The bottom sediments of the Aral Sea]. In: Sevastyanov DV, editor. Istoriya Ozer Sevan, Issyk-Kul, Balkhash, Zaisan i Aral. Leningrad: Nauka Publishing. p 239-42. In Russian.

Maev EG, Maeva SA, Nikolaev SD, Parunin OB. 1983. Novye dannye po golotsenovoi istorii Aralskogo morya [New data on the Holocene history of the Aral Sea]. In: Maev EG, editor. Paleogeografiya Kaspiiskogo i Aralskogo Morei v Kainozoe. Part 2. Moscow: Moscow State University Press. p 133-44. In Russian.

Middleton N. 2002. The Aral Sea. In: Shahgedanova M, editor. The Physical Geography of Northern Eurasia. New York: Oxford University Press. p 497-510.

Nourgaliev DK, Heller F, Borisov AS, Hajdas I, Bonani G, Iassonov PG, Oberhähsli H. 2003. Very high resolution paleosecular variation record for the last $\sim 1200$ years from the Aral Sea. Geophysical Research Letters 30(17):1914, doi:10.1029/2003GL018145.

Oberhähsli H, Boroffka N, Sorrel P, Krivonogov S. 2007. Climate variability during the past 2,000 years and past economic and irrigation activities in the Aral Sea basin. Irrigation and Drainage Systems 21:167-83.

Parunin OB, Timashkova TA, Turchaninov PS, Shlukov AI. 1985. Spisok radiouglerodnykh datirovok laboratorii noveishikh otlozheny geograficheskogo fakulteta MGU. Soobshchenie XI [The list of radiocarbon dates of the Laboratory of Recent Deposits, Faculty of Geography of the Moscow State University. Report XI]. Bulleten Komissii po Izucheniyu Chetvertichnogo Perioda 54:133-8. In Russian.

Reimer PJ, Baillie MGL, Bard E, Bayliss A, Beck JW, Blackwell PG, Bronk Ramsey C, Buck CE, Burr GS, Edwards RL, Friedrich M, Grootes PM, Guilderson TP, Hajdas I, Heaton TJ, Hogg AG, Hughen KA, Kaiser KF, Kromer B, McCormac FG, Manning SW, Reimer RW, Richards DA, Southon JR, Talamo S, Turney CSM, van der Plicht J, Weyhenmeyer CE. 2009. IntCal09 and Marine09 radiocarbon age calibration curves, 0-50,000 years cal BP. Radiocarbon 51(4): 1111-50. 
Reinhardt C, Wünnemann B, Krivonogov SK. 2008. Geomorphological evidence for the Late Holocene evolution and the Holocene lake level maximum of the Aral Sea. Geomorphology 93(3-4):302-15.

Rubanov IV, Ischniyazov DP, Baskakova MA. 1987. Geologiya Aralskogo Morya [The Geology of the Aral Sea]. Tashkent: Fan Publishing. 248 p. In Russian.

Shermatov E, Nurtayev B, Muhamedgalieva U, Shermatov U. 2004. Analysis of water resources variability of the Caspian and Aral sea basins on the basis of solar activity. Journal of Marine Systems 47(1-4):137-42.

Shnitnikov AV. 1983. Aral v golotsene i prirodnye tendentsii ego evolutsii [The Aral Sea in the Holocene and natural tendencies of its evolution]. In: Maev EG, editor. Palaeogeografiya Kaspiiskogo i Aralskogo Morei v Kainozoe. Part 2. Moscow: Moscow State University Press. p 106-18. In Russian.

Smagulov E. 2001. Nakhodka i issledovanie mazara na dne Aralskogo morya [The discovery and study of the mazar on the bottom of the Aral Sea]. Otan Tarikhy 4: 77-81. In Russian.

Smagulov E. 2002. Mavzolei na dne morya [The mausoleum on the bottom of the sea]. Qumbez 4:50-2. In Russian.

Sorrel P, Popescu S-M, Head MJ, Suc JP, Klotz S, Oberhähsli H. 2006. Hydrographic development of the Aral Sea during the last 2000 years based on a quantitative analysis of dinoflagellate cysts. Palaeogeography, Palaeoclimatology, Palaeoecology 234(1-4):304-27.

Sorrel P, Oberhähsli H, Boroffka N, Nourgaliev D, Dulski P, Röhl U. 2007. Control of wind strength and fre- quency in the Aral Sea basin during the late Holocene. Quaternary Research 67(3):371-82.

Svitoch AA. 2009. The history of the last Aral Sea. Arid Ecosystems 15(2):5-17.

Tarasov PE, Harrison SP, Saarse L, Pushenko MY, Andreev AA, Aleshinskaya ZV, Davydova NN, Dorofeyuk NI, Efremov YV, Khomutova VI, Sevastyanov DV, Tamosaitis J, Uspenskaya ON, Yakushko OF, Tarasova IV, Ya M, Elina GA, Elovicheva YK, Filimonova LV, Gunova VS, Kvavadze EV, Nuestrueva IY, Pisareva VV, Shelekhova TS, Subetto DA, Zernitskaya VP. 1996. Lake Status Records from the Former Soviet Union and Mongolia. Database Documentation Version 2. Boulder: NOAA/NGDC Paleoclimatology Program. 224 p.

van de Plassche O, editor. 1986. Sea-Level Research: A Manual for the Collection and Evaluation of Data. Norwich: Geo Books. 620 p.

Veinbergs IG. 1986. Drevnie Berega Sovetskoi Baltiki $i$ Drugikh Morei SSSR [The Ancient Coasts of the Soviet Baltic Sea and Other Seas of the USSR]. Riga: Zinatne Publishing. 168 p. In Russian.

Veinbergs IG, Stelle VY. 1980. Pozdnechetvertichnye stadii razvitiya Aralskogo morya i ikh svyaz s izmeneniyami klimaticheskikh uslovyi etogo vremeni [The Late Quaternary stages of the Aral Sea development and its connections to the climatic fluctuations of that time]. In: Andrianov BV, Zorin LV, Nikolaeva RG, editors. Kolebaniya Uvlazhnennosti Aralo-Kaspiiskogo Regiona $v$ Golotsene. Moscow: Nauka Publishing. p 175-81. In Russian.

Appendix ${ }^{14} \mathrm{C}$ dates from the Aral Sea region obtained prior to 2008.

\begin{tabular}{|c|c|c|c|c|}
\hline Locality & ${ }^{14} \mathrm{C}$ date $(\mathrm{BP})^{\mathrm{a}}$ & Lab nr & Material dated & Source $^{\mathrm{b}}$ \\
\hline Kulandy Spit & $920 \pm 120$ & LG-? & Mollusk shells ${ }^{\mathrm{c}}$ & [1] \\
\hline Core 281 & $\begin{array}{l}3700 \pm 600^{1, d} \\
1160 \pm 290^{1} \\
7980 \pm 100^{2} \\
6040 \pm 330^{2} \\
6300 \pm 330^{2}\end{array}$ & $\begin{array}{l}\text { IOAN-125 } \\
\text { IOAN-139 } \\
\text { IOAN-110 } \\
\text { IOAN-119 } \\
\text { IOAN-118 }\end{array}$ & $\begin{array}{l}\text { Total carbonates } \\
\text { Total organics } \\
\text { Total carbonates } \\
\text { Total organics } \\
\text { Wood }\end{array}$ & [2] \\
\hline Core 280 & $\begin{aligned} 4740 \pm 120^{3} \\
2950 \pm 180^{3} \\
5100 \pm 200^{4} \\
5560 \pm 460^{4} \\
10900 \pm 130\end{aligned}$ & $\begin{array}{l}\text { IOAN-116 } \\
\text { IOAN-137 } \\
\text { IOAN-113 } \\
\text { IOAN-134 } \\
\text { IOAN-111 }\end{array}$ & $\begin{array}{l}\text { Total carbonates } \\
\text { Total organics } \\
\text { Total carbonates } \\
\text { Total organics } \\
\text { Total carbonates }\end{array}$ & {$[2]$} \\
\hline Core 293 & $\begin{array}{l}2130 \pm 280 \\
1770 \pm 130^{5} \\
1870 \pm 160^{5}\end{array}$ & $\begin{array}{l}\text { IOAN-123 } \\
\text { IOAN-115 } \\
\text { IOAN-135 }\end{array}$ & $\begin{array}{l}\text { Total organics } \\
\text { Total carbonates } \\
\text { Total organics }\end{array}$ & {$[2]$} \\
\hline Core 292 & $\begin{array}{c}210 \pm 270 \\
6900 \pm 90^{6} \\
2740 \pm 110^{6}\end{array}$ & $\begin{array}{l}\text { IOAN-124 } \\
\text { IOAN-112 } \\
\text { IOAN-122 }\end{array}$ & $\begin{array}{l}\text { Total organics } \\
\text { Total carbonates } \\
\text { Total organics }\end{array}$ & {$[2]$} \\
\hline Core 15 & $1590 \pm 140$ & MGU-778 & Mollusk shells $^{\mathrm{c}}$ & [3] \\
\hline
\end{tabular}


Appendix ${ }^{14} \mathrm{C}$ dates from the Aral Sea region obtained prior to 2008. (Continued)

\begin{tabular}{|c|c|c|c|c|}
\hline Locality & ${ }^{14} \mathrm{C}$ date $(\mathrm{BP})^{\mathrm{a}}$ & Lab nr & Material dated & Source ${ }^{b}$ \\
\hline & $\begin{array}{l}3610 \pm 140 \\
4846 \pm 90 \\
4956 \pm 100\end{array}$ & $\begin{array}{l}\text { MGU-742 } \\
\text { MGU-741 } \\
\text { MGU-740 }\end{array}$ & $\begin{array}{l}\text { Mollusk shells }{ }^{\mathrm{c}} \\
\text { Mollusk shells } \\
\text { Mollusk shells }^{\mathrm{c}}\end{array}$ & \\
\hline Lazarev Islande & $970 \pm 140$ & MGU-734 & Wood & [3] \\
\hline Core 75 & $4970 \pm 110$ & IOAN-1784 & Total organics & [4] \\
\hline Core 110 & $18,340 \pm 310$ & IOAN-1781 & Total carbonates & [4] \\
\hline Core 47 & $\begin{array}{l}2870 \pm 80 \\
5570 \pm 110^{7} \\
4930 \pm 180^{7}\end{array}$ & $\begin{array}{l}\text { IOAN-1785 } \\
\text { IOAN-1782 } \\
\text { IOAN-1783 }\end{array}$ & $\begin{array}{l}\text { Total carbonates } \\
\text { Total carbonates } \\
\text { Total organics }\end{array}$ & [4] \\
\hline Core 49 & $\begin{aligned} 2030 & \pm 100^{8} \\
0 & \pm 175^{8} \\
5690 & \pm 220^{9}\end{aligned}$ & $\begin{array}{l}\text { IOAN-1375 } \\
\text { IOAN-1738 } \\
\text { IOAN-1376 }\end{array}$ & $\begin{array}{l}\text { Total carbonates } \\
\text { Total organics } \\
\text { Total carbonates }\end{array}$ & [4] \\
\hline Core 39 & $4930 \pm 180$ & IOAN-1783 & Total organics & {$[4]$} \\
\hline Core 76 & $12,250 \pm 1100$ & IOAN-1786 & Total carbonates & {$[4]$} \\
\hline Syr Dar’ya River mouth ${ }^{\mathrm{f}}$ & $12,580 \pm 370$ & IOAN-1839 & Total carbonates & {$[4]$} \\
\hline Amu Dar'ya River mouth ${ }^{\mathrm{f}}$ & $12,820 \pm 210$ & IOAN-1840 & Total carbonates & {$[4]$} \\
\hline Core 93 & $1200 \pm 200$ & MGU-876 & Mollusk shells & {$[5]$} \\
\hline Section Kulandy & $\begin{array}{l}730 \pm 80 \\
745 \pm 80\end{array}$ & $\begin{array}{l}\mathrm{Ri}-? \\
\mathrm{Ri}-?\end{array}$ & $\begin{array}{l}\text { Mollusk shells }{ }^{\mathrm{c}} \\
\text { Mollusk shells }^{\mathrm{c}}\end{array}$ & {$[6]$} \\
\hline Kulandy Spit & $2860 \pm 80$ & Ri-? & Mollusk shells ${ }^{\mathrm{c}}$ & {$[6]$} \\
\hline Core 86 & $\begin{aligned} & 4760 \pm 220 \\
& 740 \pm 120^{10} \\
& 340 \pm 160^{10} \\
& 3760 \pm 100 \\
& 1435 \pm 100 \\
& 2760 \pm 100^{11} \\
& 720 \pm 120^{11} \\
& 3480 \pm 120 \\
& 3280 \pm 100^{12} \\
& 1760 \pm 300^{12} \\
& 3160 \pm 120^{13} \\
& 1240 \pm 250^{13} \\
& 2130 \pm 180 \\
& 1480 \pm 150 \\
& 2480 \pm 100 \\
& 3200 \pm 120^{14} \\
& 1810 \pm 250^{14} \\
& 3500 \pm 100 \\
& 4540 \pm 100 \\
& 3080 \pm 80 \\
& 6760 \pm 180 \\
& 5480 \pm 80 \\
& 8000 \pm 150^{15} \\
& 4080 \pm 180^{15} \\
& 7330 \pm 220^{16} \\
& 4280 \pm 250^{16}\end{aligned}$ & $\begin{array}{l}\text { IVP-262 } \\
\text { IVP-246 } \\
\text { IVP-281 } \\
\text { IVP-247 } \\
\text { IVP-280 } \\
\text { IVP-248 } \\
\text { IVP-286 } \\
\text { IVP-249 } \\
\text { IVP-250 } \\
\text { IVP-292 } \\
\text { IVP-251 } \\
\text { IVP-295 } \\
\text { IVP-294 } \\
\text { IVP-285 } \\
\text { IVP-252 } \\
\text { IVP-253 } \\
\text { IVP-293 } \\
\text { IVP-254 } \\
\text { IVP-258 } \\
\text { IVP-273 } \\
\text { IVP-255 } \\
\text { IVP-259 } \\
\text { IVP-261 } \\
\text { IVP-260 } \\
\text { IVP-256 } \\
\text { IVP-296 }\end{array}$ & $\begin{array}{l}\text { Mollusk shells } \\
\text { Total carbonates } \\
\text { Total organics } \\
\text { Total carbonates } \\
\text { Total organics } \\
\text { Total carbonates } \\
\text { Total organics } \\
\text { Total carbonates } \\
\text { Total carbonates } \\
\text { Total organics } \\
\text { Total carbonates } \\
\text { Total organics } \\
\text { Total organics } \\
\text { Plant organics } \\
\text { Total carbonates } \\
\text { Total carbonates } \\
\text { Total organics } \\
\text { Total carbonates } \\
\text { Total carbonates } \\
\text { Plant organics } \\
\text { Total carbonates } \\
\text { Total carbonates } \\
\text { Total carbonates } \\
\text { Mollusk shells } \\
\text { Total carbonates } \\
\text { Total organics }\end{array}$ & $\begin{array}{l}{[7]} \\
{[8]}\end{array}$ \\
\hline
\end{tabular}


Appendix ${ }^{14} \mathrm{C}$ dates from the Aral Sea region obtained prior to 2008. (Continued)

\begin{tabular}{|c|c|c|c|c|}
\hline Locality & ${ }^{14} \mathrm{C}$ date (BP) ${ }^{\mathrm{a}}$ & Lab nr & Material dated & Source $^{b}$ \\
\hline & $5940 \pm 150^{17}$ & IVP-257 & Total carbonates & \\
\hline & $4910 \pm 250^{17}$ & IVP-297 & Total organics & \\
\hline & $4760 \pm 220$ & IVP-268 & Mollusk shells ${ }^{\mathrm{c}}$ & \\
\hline & $7290 \pm 100^{18}$ & IVP-270 & Total carbonates & \\
\hline & $7070 \pm 120^{18}$ & IVP-271 & Total organics & \\
\hline & $6680 \pm 150^{19}$ & IVP-259 & Total carbonates & \\
\hline & $5190 \pm 150^{19}$ & IVP-258 & Mollusk shells ${ }^{c}$ & \\
\hline & $7170 \pm 100^{20}$ & IVP-272 & Total carbonates & \\
\hline & $6040 \pm 390^{20}$ & IVP-287 & Total organics & \\
\hline & $6620 \pm 100^{21}$ & IVP-382 & Total carbonates & \\
\hline & $5700 \pm 390^{21}$ & IVP-289 & Total organics & \\
\hline \multirow[t]{4}{*}{ Core 45} & $4230 \pm 80$ & IVP-275 & Total carbonates & \multirow[t]{4}{*}{ [8] } \\
\hline & $9500 \pm 300$ & IVP-277 & Total carbonates & \\
\hline & $5450 \pm 150^{22}$ & IVP-283 & Total carbonates & \\
\hline & $1570 \pm 100^{22}$ & IVP-285 & Total organics & \\
\hline \multirow[t]{7}{*}{ Core Ar-8 } & $450 \pm 100$ & ETH-? & Macrofossils & \multirow[t]{7}{*}{ [9] } \\
\hline & $480 \pm 120$ & ETH-? & Macrofossils & \\
\hline & $655 \pm 65$ & ETH-? & Macrofossils & \\
\hline & $1095 \pm 125$ & ETH-? & Macrofossils & \\
\hline & $1145 \pm 35$ & ETH-? & Macrofossils & \\
\hline & $1495 \pm 125$ & ETH-? & Macrofossils & \\
\hline & $1470 \pm 110$ & ETH-? & Macrofossils & \\
\hline \multirow[t]{2}{*}{ Core Ar-9 } & $1145 \pm 135$ & ETH-? & Macrofossils & \multirow[t]{2}{*}{ [9] } \\
\hline & $1310 \pm 90$ & ETH-? & Macrofossils & \\
\hline South part of Butakov Bayg & $287 \pm 5^{h}$ & $?$ & Wood & [10] \\
\hline \multirow[t]{7}{*}{ Core CH2/1 } & $4860 \pm 80^{\mathrm{i}}$ & Poz-4760 & Green algae & \multirow[t]{3}{*}{ [11] } \\
\hline & $1540 \pm 30^{\mathrm{i}}$ & Poz-4756/59 & Green algae & \\
\hline & $730 \pm 30^{\mathrm{i}}$ & Poz-1351 & Total organics & \\
\hline & $1395 \pm 30$ & Poz-4762 & Green algae & \multirow[t]{2}{*}[11-12]{} \\
\hline & $1480 \pm 30$ & Poz-9662 & Mollusk shells & \\
\hline & $1521 \pm 40^{\mathrm{i}}$ & Poz-4764 & Green algae & [11] \\
\hline & $1515 \pm 25$ & Poz-4760 & Green algae & [11-12] \\
\hline \multirow[t]{2}{*}{ Core 82} & & KIA-18247 & & \multirow[t]{2}{*}[13]{} \\
\hline & $705 \pm 38$ & KIA-18248 & Water plants & \\
\hline Core in Butakov Bay & $380 \pm 40$ & $?$ & Plant macrofossils & [14] \\
\hline Core AR01-3 & $4421 \pm 55$ & $?$ & Mollusk shells ${ }^{\mathrm{c}}$ & [14] \\
\hline
\end{tabular}

an sediment cores, the ${ }^{14} \mathrm{C}$ ages are given according to depth (from top to bottom).

b Original sources indicated by numbers: [1]-Gorodetskaya (1978); [2]-Kuptsov et al. (1982); [3]-Maev et al. (1983); [4]Kuptsov (1985); [5]-Parunin et al. (1985); [6]-Veinbergs (1986); [7]-Tarasov et al. (1996); [8]-Maev and Karpychev (1999); [9]-Nourgaliev et al. (2003); [10]-Boroffka et al. (2005); [11]-Sorrel et al. (2006); [12]-Sorrel et al. (2007); [13]Filippov and Riedel (2009); [14]-Boomer et al. (2009).

${ }^{\mathrm{c}}$ Cerastoderma glaucum (formerly Cardium edule) shells.

${ }^{\mathrm{d}}$ These pairs of samples (1 through 22) are taken from the same depth.

eThis saxaul (Haloxylon sp.) stump was found in situ buried in shallow-water sediments on the island's coast.

${ }^{\mathrm{f}}$ Samples were collected from the surface of lake sediments indicating apparent ${ }^{14} \mathrm{C}$ age of the carbonate matter discharged to the reservoir.

gThis saxaul stump was found in situ on the dry bottom of the lake, elevation of $\sim 40 \mathrm{~m}$ asl (former depth of 14-15 m).

hThis value is $280 \pm 70$ BP (CAMS-2504) (sample ID 12-10-91-1) (S Stine, personal communication, 2009).

${ }^{i}$ These are calibrated dates; original ${ }^{14} \mathrm{C}$ values are not given (Sorrel et al. 2006). 